\title{
The Model of Assistance to People with Problem Eating Behavior and Weight Disorders
}

\section{Модель допомоги людям із проблемною харчовою поведінкою та порушеннями ваги}

\author{
Vitaliia Shebanova \\ Dr. in Psychology, Professor, Professor of the Department of \\ Practical Psychology, Kherson State University, Kherson (Ukraine) \\ ORCID ID: https://orcid.org/0000-0002-1658-4691 \\ Researcher ID: http://www.researcherid.com/rid/D-2740-2019 \\ E-mail: vitaliashebanova@gmail.com

\section{Віталія Шебанова} \\ Доктор психологічних наук, професор, професор кафедри \\ практичної психології, Херсонський державний університет, \\ м. Херсон (Україна)
}

\section{ABSTRACT}

The aim of the research is to determine the peculiarities of assistance to people with problem eating behavior and weight disorders in different fractals based on the principles of synergetic concept of the formation and development of problem eating behavior in the continuum "norm - pathology».

To solve the tasks set in the paper such theoretical research methods as the method of analysis of the scientific literature and generalization have been used.

The results of the research showed that synergetics in the field of psychology of eating behavior has significant heuristic potential, which determines the evolutionary methodology of the therapy and psychocorrection taking into account the phenomena of self-organization in the therapeutic space (autonomy,

Address for correspondence, e-mail: kpnu_lab_ps@ukr.net Copyright: (C) Shebanova Vitaliia

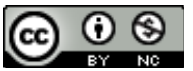

The article is licensed under CC BY-NC 4.0 International

(https://creativecommons.org/licenses/by-nc/4.0/)

(c) Shebanova Vitaliia

DOI (article): https://doi.org/10.32626/2227-6246.2021-51.241-265 
competence, self-worthiness, spiritual maturity, etc.). It is substantiated that a synergetic methodology is a tool for analyzing the nonlinear situation of the development of eating behavior. It is described that the task of specialists is to organize assistance to people with problem forms of eating behavior, aimed at finding resources to normalize patterns of eating behavior and body weight.

Conclusions. Synergetic principles and fractal modular components of the conceptual model as a holistic system give grounds to claim that the trajectory of the development at bifurcation points can be changed due to the mobilization of resource potential - activation of protective and compensatory processes of corporeity.

It may allow to outline the possibility of increasing effective assistance to people with problem eating strategies and weight deformities by: 1) identifying the peculiarities of subjective discourses as internal guidelines that determine the distorted patterns of eating behavior and, accordingly, are targets for correction; 2) rethinking the ontological problems of existence and the importance of spirituality as a resource potential of the individual, which through the activity of the spirit improves himself or herself and the socio-cultural environment; 3) organization of preventive work at the stages of latent and initial fractals, taking into account the influencing factors; 4) creation of multidisciplinary brigade forms, which include specialists from different fields of knowledge (psychologists, teachers, sociologists, clergy, physicians of various specializations, etc.); 5) creation of individual programs for normalization of eating behavior on the basis of general principles and a new approach to prevention, correction and rehabilitation of people with problem strategies of eating behavior and weight deformities.

Key words: psychology of eating behavior, problem eating behavior, body weight disorders, synergetic model of bio-psycho-socio-spiritual development of eating behavior in the continuum "norm - pathology», model of assistance.

\section{Introduction}

The relevance of the study of the psychology of human eating behavior is primarily stipulated by the social significance of the problem. The scale and rate of spreading problem eating behavior and its consequences in the form of weight disorders threaten the physical and psychological health of the population. Fixation on distorted strategies of problem eating beha(C) Shebanova Vitaliia

DOI (article): https://doi.org/10.32626/2227-6246.2021-51.241-265 
vior (EB) leads to the emergence and development of serious diseases of today (including obesity, psychogenic overeating, anorexia, bulimia), which have received the status of the social non-infectious epidemic today (according to WHO and UNESCO). On the other hand, the development of this topic has significant scientific potential, requires comprehensive research that combines different aspects of eating behavior, such as medical, psychological, pedagogical, cultural, valeological, philosophical, and others.

In our previous publications, we noted that within the traditional linear classical theories of psychosomatic development of eating behavior in the continuum «norm - pathology" there is no theory that could satisfactorily explain the causes of problem eating behavior as unsystematic destructive disorders and unstable dynamics of their development (Шебанова, 2014б; 2016в; 2017).

The concept of modern psychology of eating behavior is based on the general scientific trend of using the synergetic methodology, as it allows to combine distinctions - body and mind, material and spiritual, external and internal, collective and individual, individual and cultural-historical development, and the two most relevant methodological approaches - holistic and systemic. The use of conceptual and terminological apparatus of synergetic methodology in psychological research helps to understand common for different scientific disciplines general processes, to recognize new meanings in them, to understand the prospects of new psychological knowledge on psychosomatic development of eating behavior.

The proposed synergetic model of bio-psycho-socio-spiritual development of eating behavior in the continuum «norm - pathology" contains four vectors of ontogenetic development (somato-, psycho-, socio-, existential genesis) and four fractals, representing certain phases of the formation of problem strategies of eating behavior in the spectrum «overeating - food restriction». Three fractals (predispositions, latent and initial) 
constitute the pre-nosological period of the development, respectively, in this period it is possible to be limited to the methods of psychotherapeutic correction and general psychoprophylactic measures. The fourth fractal appears as a period of a detailed clinical picture of food-dependent diseases, and therefore in this period the normalization of eating behavior, as a restorative therapy of holistic health, requires the involvement of specialists from different fields: psychologists, physicians of various specializations, and others (Шебанова, 2014б; 2016в; 2017).

The phenomenology of the formation and the course of problem eating behavior in the synergetic bio-psycho-sociospiritual model are positioned by the multi-vector ontogenetic development and the scale of fractals that determine the diversity of dynamic nonlinear development. The model allows to trace the process of the development of problem variants of eating behavior in the spectrum of pathological mode "overeating - food restriction» from the moment of favorable preconditions to the detailed clinical picture of the corresponding nosological forms (obesity, psychogenic overeating, anorexia, bulimia), moreover bodyweight deformities (weight deficit or overweight) are considered as somatic equivalents of problem patterns of eating behavior.

The peculiarity of the conceptual model of the development of eating behavior in the continuum «norm - pathology» is that it allows considering the emergence of various deviations at the bifurcation points as ways of spontaneous self-organization of the system to its disintegration and self-destruction which corresponds to the extreme variants of the detailed clinical picture of food-dependent diseases. Thus, the processes of formation of different problem types of eating behavior are the variants of self-development of the metasyndrom system of metacasual nature, which arise in the conditions of imbalance and are determined by attractors of the system as new ordered structures to which disordered structures gravitate. The model (C) Shebanova Vitaliia

DOI (article): https://doi.org/10.32626/2227-6246.2021-51.241-265 
provides grounds for understanding food-dependent diseases as scenarios of transition from problem eating behavior strategies in the spectrum "overeating - food restriction" to chaos (attractors of obesity and eating disorders) through a cascade of bifurcations in the corporal system. It is important to take into account the retrospective and perspective of the system, because its current state, on the one hand, is the result of past and future development of the system.

The development of nonlinear dynamic theory made it possible to establish how the interaction of various factors affects the evolution of metasyndrom formation of eating behavior as a phenomenological phenomenon of corporeality - from relative equilibrium to intrasystem endogenous chaos (as an attractor of food-dependent diseases) and to find out how reverse processes develop in this system that contributes to the normalization of eating behavior. The synergetic concept of the formation of eating behavior in the continuum «norm pathology» takes into account the adverse effects of external and internal factors that distort EB patterns and their further pathogenetic development in the direction of multiple disorders at all levels of corporeality. The model takes into account the main conditions of psychosomatic diseases, which were identified by several authors, in particular, the vulnerability of organs and systems due to hereditary burden («X» factor), features of the intrapsychic level of corporeality; «Starting situation" (as a trigger stress mechanism), the power of the subjective "Self», etc., which was considered by us in our previous publications (Шебанова, 2014a; 2014б, 2014в; 2014г; 2016а; 2016б; 2016в; 2017).

The aim of the article is to determine the peculiarities of providing assistance to people with problem eating behavior and weight disoders in different fractals based on the principles of synergetic concept of the formation and development of problem eating behavior in the continuum «norm - patho$\log y »$.

(c) Shebanova Vitaliia

DOI (article): https://doi.org/10.32626/2227-6246.2021-51.241-265 


\section{The task of the article}

Based on the relevance and insufficient development of the problem concerned, we have identified the following research objectives: 1) to identify the categories of people who can provide assistance to people with problem eating behavior and weight disorders based on the principles of synergetic concept of the formation and development of problem eating behavior in the continuum «norm - pathology»; 2) to determine the peculiarities of providing assistance to people with problem eating behavior and weight disorders in different fractals of the synergetic model.

\section{Research methods and techniques}

In order to solve the tasks formulated in the article, the following theoretical research methods were used: the method of analysis of the scientific literature and generalization.

\section{Results and discussions}

Our theoretical and methodological principles of the synergetic concept of the emergence and development of problem eating behavior in the continuum "norm - pathology» make it possible to organize early prevention of problem forms of eating behavior and weight deformities at the subclinical (prenosological) level (Шебанова, 2014б; 2016в; 2017). Taking into account the need to help people with different forms of problem eating behavior in the realization of their life potential, this is a particularly urgent task. Thus, the combination of a synergetic approach with the concept of ontogenetic development (somato-, psycho-, socio-, and existential genesis) allowed to build a single methodology of analysis for the whole variable spectrum of problem eating behavior (all types and forms) and explain their formation regardless of nosological form and age.

Based on the principles of the synergetic concept, it is possible to answer current questions of the psychology of eating (C) Shebanova Vitaliia

DOI (article): https://doi.org/10.32626/2227-6246.2021-51.241-265 
DOI: https://doi.org/10.32626/2227-6246.2021-51

2021. ВиПУСК 51

behavior, in particular, on some issues of eating disorders in the spectrum "overeating - refusal to eat» and their somatic equivalents (in the form of weight deficit or overweight):

1) What triggers do determine the appearance of distorted patterns of eating behavior and stipulate the further process of psychopathogenetic development?

2) Why do stimulus traumatic situations distort the patterns of eating behavior with the further development of the psychopathogenic process for some people, and for others don't; why is «food» or «eating situation» the stimulus traumatic factors in some cases, and in others, these are «standards of the body», "reactions of others», etc.?

3) Why do the same types of mental trauma in different people lead to different types of eating disorders and why can different psychogenic injuries in different people lead to a certain type of eating disorder?

The synergetic approach leads to a significant revision of the ideology and methodology for prevention, psycho-correctional measures, and rehabilitation strategies to help people with problem forms of eating behavior and its negative consequences - real or imagined overweight.

Psychotherapeutic correction of strategies of the pathological mode of EB in the spectrum «overeating - refusal to eat» based on a synergetic model opens new opportunities and prospects for helping people with problem eating behavior (subclinical and clinical signs of EB disorders). The main rehabilitation and prevention priority of this model is a high quality of life based on the normalization of eating behavior and weight, as a choice of healthy lifestyle and style of life.

Synergetic model of bio-psycho-socio-spiritual development of eating behavior in the continuum «norm - pathology" focuses on the creation of multidisciplinary (psychological, medical, and social) brigade forms of assistance to people with problem eating behavior, including medical professionals (psychiatrists, endocrinologists, therapists, and in case of compli-

(c) Shebanova Vitaliia

DOI (article): https://doi.org/10.32626/2227-6246.2021-51.241-265 
cations - gynecologists, gastroenterologists, dermatologists, cardiologists, etc.); specialists in the field of mental health (practical and clinical psychologists, psychotherapists), specialists in the field of education, social services, representatives of the patriarchal psychotherapy and other specialists in the mental health service.

The fractal of predisposition of the considered model focuses on carrying out preventive and corrective measures with the alimentary family. At the same time, on the one hand, organizational work should be aimed at identifying family dysfunctions and hereditary psychophysiological predisposition to problem eating behavior in the spectrum «overeating - refusal to eat», on the other hand, it should be aimed at harmonization of family relationships and increasing personal maturity (formation of a harmonious image of subjective «Self»).

The latent fractal of the model focuses on the detection of dysfunctional physiological and psychosomatic reactions caused by alimentary diathesis. Among the important measures of this stage there are anthropometric measurements (body diameter, body mass index, percentage of fat and muscle tissue in the body, etc.), diagnosis and correction (feeling of chronic dissatisfaction with weight, body, self, and life in general, stylistic features of eating behavior: a tendency to manifestations of problematic stereotypes of eating behavior by emotional, external and restrictive types; disharmonious socialization of personality and value-semantic disharmonies, etc.).

Adequate psychoprophylaxis and psychocorrection within this fractal are very important measures, as their main task is to prevent the transition of problematic forms of eating behavior to the next initial fractal.

Within the initial fractal, when specific problem strategies of eating behavior in the spectrum «overeating - refusal to eat» and their somatic equivalents in the form of a tendency to weight deficit or overweight are revealed, it is possible to use drug-free and pharmacological measures preventing the (C) Shebanova Vitaliia

DOI (article): https://doi.org/10.32626/2227-6246.2021-51.241-265 
pathogenetic development of the disorders of eating behavior and weight.

It should be noted the possibility of assisting with the use of non-pharmacological products. Among them there are psychophysiological and psychological methods of psychotherapeutic correction: «control of hunger and satiation", "control of food strategies and taste preferences against the background of weight control and nutrition»; "control and correction of the emotional state»; clarification of the psychological meaning of food in the situation of food consumption, increasing selfesteem and the need to take care of yourself, conflict resolution, optimization of interpersonal relationships; dosed physical activity, etc. (Вознесенская, Сафонова \& Платонова, 2000; Гетманчук, 2012; Гряділь, Чубірко, Чопей \& Гечко, 2015; Дука, 2016; da Luz, Наy, Touyz \& Sainsbury, 2018; Fisher, Skocic, Rutherford \& Hetrick, 2018; Saltzman \& Liechty, 2016; Schaumberg, Welch, Breithaupt, Hübel \& et all., 2017; Troscianko \& Leon, 2020).

The specificity of the life situation that arises due to the presence of problem forms of eating behavior in the spectrum «overeating - refusal to eat» is determined by «sudden» weight shifts (overweight and weight deficit). Accordingly, the first diagnosis at this stage stipulates the necessity of conducting targeted correction and psychorehabilitation, as «failure to respond» to the first clinical signs of «a future illness» leads to serious psychosomatic complications in the future.

The fractal of the developed clinical picture focuses on conducting early qualified medical, psychological, spiritual and moral, social, educational / pedagogical assistance. The specificity of the life situation of this fractal is determined by the vital threat (due to "overlaying" the symptoms of other serious disorders), the risk of disability, loss of social status, low level of social protection, and the need to carry out individual psychotherapeutic correction and rehabilitation program. Differences which are stipulated by the peculiarities of

(c) Shebanova Vitaliia

DOI (article): https://doi.org/10.32626/2227-6246.2021-51.241-265 
DOI: https://doi.org/10.32626/2227-6246.2021-51 2021. випуск 51 the pathogenetic development of eating behavior in the spectrum of "overeating - refusal to eat» and disorders of body weight determine different approaches to non-pharmacological (psychotherapeutic correction, diet, physical activity) and pharmacological therapy. Leading specialists in the field of psychosomatics, the psychology of corporeality, and psychiatry express the opinion about the need to include a psychotherapeutic correction in the arsenal of mandatory treatment of patients with eating disorders and obesity (Вознесенская, Сафонова \& Платонова, 2000; Гетманчук, 2012; Гряділь, Чубірко, Чопей \& Гечко, 2015; Дука, 2016; Chevinsky, Wadden \& Chao, 2020; Rousselet, Guérineau, Paruit, Guinot \& et all., 2017; Zipfel, Giel, Bulik, Hay \& et all., 2015).

According to them, the means of correction allow correcting various psychological causes of painful eating behavior (thoughts with cognitive defects that cause problems with eating, automatic thoughts, unhealthy attitude to food and its consumption, inadequate perception of their appearance, etc.).

Besides, the means of psychotherapeutic correction can reveal hidden internal resources, which will significantly increase the chances of effective therapy. According to S. O. Kulakov, internal resources form an internal contour of self-organization, which has its hierarchical structure and functions in parallel with the contour of the disease (Кулаков, 2009: 129). However, M. V. Savchin, defining the spiritual as a deep subjectivity and causal series that fundamentally affects a person's mental health, optimizing their life, emphasizes that the consequences of the interaction of spiritual with mental are to reduce levels of egocentrism, passion, dependence from material and physical, mental and social needs: «It is established that when a person masters the higher spiritual states, the center of his or her Self shifts from the somatic, psychological and social spheres to the spiritual sphere, the Self-ideal is identified with these states» (Савчин, 2013: 194-195).

(C) Shebanova Vitaliia

DOI (article): https://doi.org/10.32626/2227-6246.2021-51.241-265 
Sharing these positions, we believe that the restoration of resource status is possible due to the ability to accept help (psychological, social, moral), awareness of the severity of problem forms of eating behavior, recognition of painful / abnormal EB, the need to take responsibility for their lives and change behavior and lifestyle, philosophical and religious attitude to the end of existence, the revival of the power of spirit, readiness to overcome difficulties on the way to their health, and so on.

The use of multidimensional diagnostics makes it possible to systematize data according to the main planes of the biopsycho-socio-spiritual model, to analyze the relationships and evaluate the provoking and resource factors, which in synergetics are called «disease attractors» or «health attractors» (attractors), which will allow making an individual program of psychocorrection and rehabilitation.

The model allows determining the ways of psychotherapeutic correction for different types of problem eating behavior and weight disorders, taking into account their fundamental differences. First of all, the model points to the necessity of conducting psychocorrectional work in four areas: restoration of contact with the body (according to the vector of somatogenesis); harmonization of "relationship with food" (clarification of the psychological meaning of food in the eating process), optimization of relations with others and focus on true self-care (according to the vectors of psycho-, socio-, and existential genesis) (Шебанова, 2014д). In case of complications or recurrences of problem eating behavior, secondary and tertiary psychoprophylaxis measures are carried out, i.e. rehabilitation (psychological, medical, social) is carried out.

Synergetics in the field of the psychology of eating behavior has significant heuristic potential, which determines the evolutionary methodology of therapy and psychocorrection taking into account the phenomena of self-organization of the individual in the therapeutic space (autonomy, competence,

(c) Shebanova Vitaliia

DOI (article): https://doi.org/10.32626/2227-6246.2021-51.241-265 
DOI: https://doi.org/10.32626/2227-6246.2021-51

2021. випуск 51

self-worthiness, spiritual maturity, etc.). Thus, the synergetic methodology is a tool for analyzing the nonlinear situation of the development of eating behavior. This follows from the positive attitude of the synergetic approach: the individual has the resource to self-organization and self-restoration. The task of specialists is to help people with problem forms of eating behavior, aimed at finding resources to normalize patterns of eating behavior and body weight. This is particularly relevant in connection with the complexity of living requirements, with an increase of unfavorable stress effects, resulting in an increase in morbidity and mortality from such «diseases of civilization» as disorders of eating behavior (anorexia, bulimia, psychogenic overeating) and obesity. The synergetic approach makes it possible to see the complexity of the interaction of various factors that may affect the course of problematic strategies of eating behavior in the continuum «norm - pathology». It is noted that the span of life is affected not only by the ratio of pathogenic and protective factors but also by coincidences that occur near the bifurcation points. Psychotherapeutic correction, therapy, rehabilitation, and prevention of problem eating behavior provide the ability to rely on protective personality factors that make up the resource potential of the individual. We also refer health protection eating behavior to the resource potential of the individual, which is both an individual resource of the individual (personal choice of life) and collective socio-cultural orientation of the individual on eating behavior (which we considered in Shebanova's publication, 2019). Resource (sanogenic) potential makes it possible to choose the most optimal strategies and tactics for overcoming difficulties in normalizing eating behavior and weight, reducing stress, maintaining freedom of behavior, including food. In other words, the resource potential of the individual allows one to choose consciously the option of life that corresponds to his or her individual development and allows living a healthy (C) Shebanova Vitaliia

DOI (article): https://doi.org/10.32626/2227-6246.2021-51.241-265 
and prosperous life. Resource potential is divided into three groups:

- the first group of resource potential contains protective factors that are formed by the social environment (micro-, macro-society, upbringing, education, media), and determine the way and conditions of life (it is external to the individual);

- the second group contains "hidden resources» of the individual, which are activated («revealed») under the influence of joint work with specialists (psychologist / psychotherapist / psychiatrist, nutritionist, doctor, social worker, teacher, fitness trainer, etc.). The subject «discovers» these resources in psychotherapeutic correction sessions, in personal development groups, fitness groups, and others, which help to increase physical and psychological stability, communicative competence, self-confidence, etc.;

- the third group of resource potential contains such protective qualities which the subject reveals and develops in themselves independently due to the expansion of the zone of awareness of internal resources and spirituality, as their responsibility for eating behavior, for their body, their health, for themselves as a whole, their way of life. Responsibility for one's eating behavior, one's body, and one's health, in general, is a process aimed at taking care of one's «external» and «internal» body, the ability to make decisions following one's internal feelings; the ability to resist the «blind», meaningless copying of fashion trends as to corporeity, mastering the skills necessary to maintain health at a high level. Thus, the responsibility for health protection eating behavior, as a manifestation of spirituality, is one of the most important resources for the normalization of problem eating behavior.

The main strategy of psychological assistance in the field of the existential genesis of the presented model is to expand the internal potential by realizing the "to be» tendency", through which the individual rethinks the circumstances of his or her life and his or her potential, transforms meanings

(c) Shebanova Vitaliia

DOI (article): https://doi.org/10.32626/2227-6246.2021-51.241-265 
DOI: https://doi.org/10.32626/2227-6246.2021-51 2021. випуск 51 and becomes a self-sufficient subject of vital activity. From that moment, he or she can change his or her attitudes about the possibility of normalizing the patterns of eating behavior and his or her body weight, and to provide self-help (meaning to find the resources to overcome the difficulties of life due to the presence of problem eating behavior). A special danger for people with problem eating behavior is the feeling of helplessness, the possibility of losing control over eating behavior, and consequently, over their body weight, which often leads to a suicidal mood. We share the position of some authors of humanistic and existential directions of psychology and psychotherapy, who claim that an effective counteraction to suicidal intentions is to increase the level of spirituality (Боришевський, 2010; Климишин, 2012; Колісник, 2010; Осьодло, 2009; Ставицька, 2014; Титаренко, 2011). «Thanks to spirituality, a person becomes significantly less dependent on external circumstances (he or she is not even afraid of the prospect of being left without the support of others, he or she sees no point in being liked by others in all situations, feels his or her ability to influence the events, develops capabilities, etc.) and becomes a self-sufficient subject who is responsible for his or her life (Savchin, 2013: 195).

Concluding this section, we note that we share the opinion of a pleiad of authors (M.-L. A. Chepa, V. F. Matsenko, Zh. M. Matsenko, A. D. Tereshchuk, etc.), who note that the synergistic approach is not another escape into metaphors and is not a disguise of psychology into fashionable natural science terminology: we are dealing here with an elegant possibility of synthesizing phenomenological and categorical knowledge about the psyche and society» (Чепа, Маценко, Маценко, Терещук та ін., 2015: 195).

\section{Conclusions}

Synergetic principles and fractal modular components of the conceptual model as a holistic system give grounds to claim (c) Shebanova Vitaliia

DOI (article): https://doi.org/10.32626/2227-6246.2021-51.241-265 
that the trajectory of the development at bifurcation points can be changed due to the mobilization of resource potential activation of protective and compensatory processes of corporeity.

It may allow to outline the possibility of increasing effective assistance to people with problem eating strategies and weight deformities by: 1) identifying the peculiarities of subjective discourses as internal guidelines that determine the distorted patterns of eating behavior and, accordingly, are targets for correction; 2) rethinking the ontological problems of existence and the importance of spirituality as a resource potential of the individual, which through the activity of the spirit improves itself and the socio-cultural environment; 3) organization of preventive work at the stages of latent and initial fractals, taking into account the influencing factors; 4) creation of multidisciplinary brigade forms, which include specialists from different fields of knowledge (psychologists, teachers, sociologists, clergy, physicians of various specializations, etc.); 5) creation of individual programs for normalization of eating behavior on the basis of general principles and a new approach to prevention, correction and rehabilitation of people with problem strategies of eating behavior and weight deformities.

\section{Literature}

Боришевський М. Й. Дорога до себе: від основ суб'єктності до вершин духовності. Київ : Академвидав, 2010. 416 с.

Вознесенская Т. Г., Сафонова В. А., Платонова Н. М. Нарушения пищевого поведения и коморбидные синдромы при ожирении и методы их коррекции. Журнал неврологии и психиатрии ил. С. С. Корсакова. 2000. № 12. С. 49-52.

Гетманчук Є. I. Медико-психологічні та патоперсонологічні аспекти психогенної гіперфагії. Медична психологія. 2012. № 3. С. 17-21.

Гряділь Т. І., Чубірко К. І., Чопей І. В., Гечко М. М. та ін. Діагностика, лікування та профілактика ожиріння. Україна. Здоров’я нацї. 2015. № 1. С. 96-100.

(c) Shebanova Vitaliia

DOI (article): https://doi.org/10.32626/2227-6246.2021-51.241-265 
DOI: https://doi.org/10.32626/2227-6246.2021-51 2021. випУСК 51

Дука Ю. М. Патогенетичне обгрунтування діагностики, лікувальної тактики та профілактики виникнення системних порушень у вагітних жінок з надмірною масою тіла: автореф. дис. ... д-ра мед. наук: 14.01.01. Київ, 2016. 40 с.

Кулаков С. А. Биопсихосоциодуховная и синергетическая модель развития онкологического заболевания: системный поход. Известия Российского государственного педагогического университета ил. А. И. Гериена. 2009. Вып. 100. С. 124-131.

Климишин О. І. Духовна терапія адиктивних осіб: християнсько-орієнтований підхід. Івано-Франківськ : Гостинець, 2012. 121 с.

Колісник О. П. Духовні практики як активний метод саморозвитку особистості в перехідний період суспільства. Психологічні перспективи. 2010. Вип. 16. С. 101-118.

Осьодло В. І. Когнітивні та екзистенційні феномени психіки в контексті самодетермінації. Вісник НАОУ. 2009. № 4 (12). С. 107-112.

Савчин М. В. Духовна парадигма в психології. Київ : Академвидав, 2013. 252 c.

Ставицька С. О. Теоретичний аналіз проблеми механізмів розвитку духовної самосвідомості особистості в юнацькому віці. Проблели сучасної психологї: зб. наук. праць Кам'янець-Подільського національного університету ілені Івана Огієнка, Інституту психологї імені Г. С. Костюка НАПН України / за ред. С. Д. Максименка, Л. А. Онуфрієвої. Кам'янець-Подільський : Аксіома, 2014. Вип. 24. С. 630-645.

Титаренко Т. М. Його величність випадок: несподівані конфігурації людського життя. Психологія особистості. 2011. № 1 (2). С. 153-158.

Чепа М.-Л. А., Маценко В. Ф., Маценко Ж⿱. М., Терещук А. Д. та ін. Психосинергетичні особливості сталих та кризових періодів життя людини: монографія / за ред. Чепи М.-Л. А. Київ : Педагогічна думка, 2015. 197 с.

Шебанова В. І., Шебанова С. Г. Перекручені патерни харчової поведінки як невротичний ритуал. Науковий вісник Херсонського державного університету: зб. наук. праць. Серія: Психологічні нау$\kappa и$ / гол. ред. О. Є. Блинова. Херсон : Видавничий дім «Гельветика», 2014а. Вип. 2. Т. 1. С. 148-155.

Шебанова В. І. Синергетична модель розвитку розладів харчової поведінки. Практична психологія та соціальна робота. 2014б. № 12. C. $1-18$.

Шебанова В. I. Харчова поведінка в структурі тілесності: теоретичні й методологічні основи тілесності. Науковий вісник Херсонського державного університету: зб. наук. пращь. Серія: Психологічні на-

(C) Shebanova Vitaliia

DOI (article): https://doi.org/10.32626/2227-6246.2021-51.241-265 
уки / гол. ред. О. Є. Блинова. Херсон : Видавничий дім «Гельветика», 2014в. Вип. 1. С. 186-192.

Шебанова В. I. Іпохондричний дискурс сучасності як базова основа викривленої турботи про себе (нав'язливе прагнення зниження ваги). Проблели сучасної психологї: зб. наук. праць Кал'янець-Подільського національного університету ілені Івана Огієнка, Інституту психологї іл. Г. С. Костюка НАПН Украӥни / за наук. ред. С. Д. Максименка, Л. А. Онуфрієвої. Кам'янець-Подільський : Аксіома, 2014г. Вип. 25. С. 638- 651.

Шебанова В. И. Тренинг нормализации пищевого поведения: Программа психологического сопровождения на пути к свободе от переедания. Практическое руководство. Херсон : ПП Вишемирский В. С., 2014 д. 394 с.

Шебанова В. І. Ситуація харчового насильства як детермінація викривлення патернів харчової поведінки. Науковий вісник Херсонського державного університету: зб. наук. праць. Серія: Психологічні науки / гол. ред. О. Є. Блинова. Херсон : Видавничий дім «Гельветика», 2016а. Вип. 1. Т. 1. С. 111-118.

Шебанова В. I. Вплив різноманітних форм харчового насильства на особливості суб'єктивної картини життєвого шляху. New Trends of Global scientific ideas 2016: material of proceedings of the International scientific-practical congress of pedagogues, psychologists and medics the of 10ht of May, Geneva (Switzertland). 2016 . C. $158-161$.

Шебанова В. І. Феноменологія харчової поведінки у континуумі «норма - патологія». Херсон : ПП Вишемирський В. С., 2016в. 612 с.

Шебанова В. І. Психологія харчової поведінки: дис. ... д-ра психол. наук: 19.00.01. Київ, 2017. 562 с.

Шебанова В. I. Психологічні умови та технології формування здоров'язбережувальної компетентності щодо харчової поведінки. Пси хологічні технологї ефективного функціонування та розвитку особистості: монографія / за ред. С. Д. Максименка, С. Б. Кузікової, В. Л. Зливкова. Суми : Вид-во СумДПУ імені А. С. Макаренка, 2019. С. 506-530.

Chevinsky, J. D., Wadden, T. A., \& Chao, A. M. (2020). Binge Eating Disorder in Patients with Type 2 Diabetes: Diagnostic and Management Challenges. Diabetes, metabolic syndrome and obesity: targets and therapy, 13, 1117-1131. URL : https://doi.org/10.2147/DMSO. S213379.

da Luz, F. Q., Hay, P., Touyz, S., \& Sainsbury, A. (2018). Obesity with Comorbid Eating Disorders: Associated Health Risks and Treatment

(c) Shebanova Vitaliia

DOI (article): https://doi.org/10.32626/2227-6246.2021-51.241-265 
DOI: https://doi.org/10.32626/2227-6246.2021-51 2021. випУСК 51

Approaches. Nutrients, 10 (7), 829. URL : https://doi.org/10.3390/ nu10070829.

Fisher, C. A., Skocic, S., Rutherford, K. A., \& Hetrick, S. E. (2018). Family therapy approaches for anorexia nervosa. The Cochrane database of systematic reviews, 10 (10), CD004780. URL : https://doi. org/10.1002/14651858.CD004780.pub3.

Gutierrez, E., \& Birmingham, C. L. (2020). Editorial: New Perspectives to Unlock the Current Impasse in Treating Anorexia Nervosa. Frontiers in psychology, 11, 207. URL : https://doi.org/10.3389/ fpsyg.2020.00207.

Rousselet, M., Guérineau, B., Paruit, M., Guinot, M., \& et all. (2017). Disordered eating in French high-level athletes: Association with type of sport, doping behavior, and psychological features. Eating and Weight Disorders, 22, 61-68. URL : https://doi.org/10.1007/ s40519-016-0342-0.

Saltzman, J. A., \& Liechty, J. M. (2016). Family correlates of childhood binge eating: A systematic review. Eating Behaviors, 22, 62-71. URL : https://doi.org/10.1016/j.eatbeh.2016.03.027.

Schaumberg, K., Welch, E., Breithaupt, L., Hübel, C., \& et all. (2017). The Science Behind the Academy for Eating Disorders' Nine Truths About Eating Disorders. European eating disorders review: the journal of the Eating Disorders Association, 25 (6), 432-450. URL : https://doi.org/10.1002/erv.2553.

Troscianko, E. T., \& Leon, M. (2020). Treating Eating: A Dynamical Systems Model of Eating Disorders. Frontiers in psychology, 11, 1801. URL : https://doi.org/10.3389/fpsyg.2020.01801.

Zipfel, S, Giel, K. E, Bulik, C. M, Hay, P., \& et all. (2015). Anorexia nervosa: Aetiology, assessment, and treatment. Lancet Psychiatry, 2, 1099-1111. URL : https://doi.org/10.1016/S2215-0366(15)00356-9.

\section{References}

Boryshevskyi, M. Y. (2010). Doroha do sebe: vid osnov subiektnosti do vershyn dukhounosti [The road to oneself: from the foundations of subjectivity to the peaks of spirituality]. Kyiv : Akademvydav [in Ukrainian].

Voznesenskaia, T. G., Safonova, V. A., \& Platonova, N. M. (2000). Narusheniia pishchevogo povedeniia i komorbidnyie sindromy pri ozhirenii i metody ikh korrektsii [Eating disorders and comorbid syndromes in obesity and methods of their correction]. Zhurnal nevrologii i psikhiatrii im. S. S. Korsakova - Journal of Neurology and Psychiatry named after S. S. Korsakov, 12, 49-52 [in Russian].

(C) Shebanova Vitaliia

DOI (article): https://doi.org/10.32626/2227-6246.2021-51.241-265 
Hetmanchuk, Ye. I. (2012). Medyko-psykholohichni ta patopersonolohichni aspekty psykhohennoi hiperfahii [Medico-psychological and pathopersonal aspects of psychogenic hyperphagia]. Medychna psykholohiiaMedical psychology, 3, 17-21 [in Ukrainian].

Hriadil, T. I., Chubirko, K. I., Chopei, I. V., Hechko, M. M., \& and others (2015). Diahnostyka, likuvannia ta profilaktyka ozhyrinnia [Diagnosis, treatment and prevention of obesity]. Ukraina. Zdoroviia natsiiUkraine. Health of the nation, 1, 96-100 [in Ukrainian].

Duka, Yu. M. (2016). Patohenetychne obgruntuvannia diahnostyky, likuvalnoi taktyky ta profilaktyky vynyknennia systemnykh porushen $\mathrm{u}$ vahitnykh zhinok z nadmirnoiu masoiu tila [Pathogenetic substantiation of diagnostics, treatment tactics and prevention of systemic disorders in pregnant women with overweight]. Extended abstract of Doctor's thesis. Kyiv [in Ukrainian].

Kulakov, S. A. (2009). Biopsikhosotsiodukhovnaia i sinergeticheskaia model razvitiia onkologicheskogo zabolevaniia: sistemnyi podkhod [Biopsychosocio-spiritual and synergetic model of oncological disease development: systemic approach]. Izvestiia Rossiiskogo gosudarstvennogo pedagogicheskogo universiteta im. A. I. Gertsena - Proceedings of the Russian State Pedagogical University named after A. I. Herzen, 100, 124-131 [in Russian].

Klymyshyn, O. I. (2012). Dukhouna terapiia adyktyvnykh osib: khrystyiansko-oriientovanyi pidkhid [Spiritual therapy of addictive persons: a Christian-oriented approach]. Ivano-Frankivsk : Gostynets [in Ukrainian].

Kolisnyk, O. P. (2010). Dukhovni praktyky yak aktyvnyi metod samorozvytku osobystosti $\mathrm{v}$ perekhidnyi period suspilstva [Spiritual practices as an active method of personal self-development in the transition period of society]. Psykholohichni perspektyvy - Psychological perspectives, 16, 101-118 [in Ukrainian].

Osiodlo, V. I. (2009). Kohnityvni ta ekzystentsiini fenomeny psykhiky v konteksti samodeterminatsii [Cognitive and existential phenomena of the psyche in the context of self-determination]. Visnyk NAOU Visnyk NAOU, 4 (12), 107-112 [in Ukrainian].

Savchyn, M. V. (2013). Dukhouna paradyhma v psykholohii [Spiritual paradigm in psychology]. Kyiv : Akademvydav [in Ukrainian].

Stavytska, S. O. (2014). Teoretychnyi analiz problemy mekhanizmiv rozvytku dukhovnoi samosvidomosti osobystosti $\mathrm{v}$ yunatskomu vitsi [Theoretical analysis of the problem of mechanisms of development of spiritual self-consciousness of a person in adolescence]. Problemy suchasnoi psykholohii: zb. nauk. prats KPNU imeni Ivana Ohiienka,

(c) Shebanova Vitaliia

DOI (article): https://doi.org/10.32626/2227-6246.2021-51.241-265 
DOI: https://doi.org/10.32626/2227-6246.2021-51 2021. випУСК 51

Instytutu psykholohii imeni H. S. Kostiuka NAPN Ukrainy - Problems of modern psychology: collection of research papers of Kamianets-Podilskyi National Ivan Ohiienko University, G. S. Kostiuk Institute of Psychology of the National Academy of Educational Sciences of Ukraine, 24, 630-645. Kamianets-Podilskyi : Aksioma [in Ukrainian].

Tytarenko, T. M. (2011). Yoho velychnist vypadok: nespodivani konfihuratsii liudskoho zhyttia [His Majesty's Case: unexpected configurations of human life]. Psykholohiia osobystosti - Personality psychology, 1 (2), 153-158 [in Ukrainian].

Chepa, M.-L. A., Matsenko, V. F., Matsenko, Zh. M., Tereshchuk, A. D., \& and others (2015). Psykhosynerhetychni osoblyvosti stalykh ta kryzovykh periodiv zhyttia liudyny [Psychosynergetic features of stable and crisis periods of human life]. Kyiv : Pedahohichna dumka [in Ukrainian].

Shebanova, V. I., \& Shebanova, S. G. (2014a). Perekrucheni paterny kharchovoi povedinky yak nevrotychnyi rytual [Distorted patterns of eating behavior as a neurotic ritual]. Naukovyi visnyk Khersonskoho derzhavnoho universytetu: Seriia: Psykholohichni nauky - Scientific Bulletin of Kherson State University. Series: Psychological Sciences, 2 (1), 148-155. Kherson : Vydavnychyi dim «Helvetyka» [in Ukrainian].

Shebanova, V. I. (2014b). Synerhetychna model rozvytku rozladiv kharchovoi povedinky [Synergetic model of development of eating disorders]. Praktychna psykholohiia ta sotsialna robota - Practical Psychology and Social Work, 12, 1-18 [in Ukrainian].

Shebanova, V. I. (2014v). Kharchova povedinka v strukturi tilesnosti: teoretychni i metodolohichni osnovy tilesnosti [Food behavior in the structure of corporeality: theoretical and methodological foundations of corporeality]. Naukovyi visnyk Khersonskoho derzhavnoho universytetu. Seriia: Psykholohichni nauky - Scientific Bulletin of Kherson State University. Series Psychological Sciences, 1, 186-192. Kherson : Vydavnychyi dim «Helvetyka» [in Ukrainian].

Shebanova, V. I. (2014g). Ipokhondrychnyi dyskurs suchasnosti yak bazova osnova vykryvlenoi turboty pro sebe (naviazlyve prahnennia znyzhennia vahy) [Hypochondriac discourse of modernity as a basis for distorted self-care (obsessive desire to lose weight)]. Problemy suchasnoi psykholohii: zb. nauk. prats KPNU imeni Ivana Ohiienka, Instytutu psykholohii imeni H. S. Kostiuka NAPN Ukrainy - Problems of modern psychology: collection of research papers of Kamianets-Podilskyi National Ivan Ohiienko University, G. S. Kostiuk Institute (C) Shebanova Vitaliia

DOI (article): https://doi.org/10.32626/2227-6246.2021-51.241-265 
DOI: https://doi.org/10.32626/2227-6246.2021-51 2021. випУСК 51

of Psychology of the National Academy of Educational Sciences of Ukraine, 25, 638-651. Kamianets-Podilskyi : Aksioma [in Ukrainian].

Shebanova, V. I. (2014d). Trening normalizatsii pishchevogo povedeniia: Programma psikhologicheskogo soprovozhdeniia na puti $k$ svobode ot pereiedaniia [Training in the normalization of eating behavior: A program of psychological support on the way to freedom from overeating]. Kherson : PP Vishemirskii V. S. [in Russian].

Shebanova, V. I. (2016a). Sytuatsiia kharchovoho nasylstva yak determinatsiia vykryvlennia paterniv kharchovoi povedinky [The situation of food violence as a determination of distortion of patterns of food behavior]. Naukovyi visnyk Khersonskoho derzhavnoho universytetu. Seriia: Psykholohichni nauky - Scientific Bulletin of Kherson State University. Series: Psychological Sciences, 1 (1), 111-118. Kherson : Vydavnychyi dim «Helvetyka» [in Ukrainian].

Shebanova, V. I. (2016b). Vplyv riznomanitnykh form kharchovoho nasylstva na osoblyvosti subiektyvnoi kartyny zhyttievoho shliakhu [Influence of various forms of food violence on the peculiarities of the subjective picture of life]. New Trends of Global scientific ideas 2016: material of the proceedings of the International scientific-practical congress of pedagogues, psychologists and medics of 10ht of May, (pp. 158-161). Geneva (Switzerland).

Shebanova, V. I. (2016v). Fenomenolohiia kharchovoi povedinky u kontynuumi «norma - patolohiia» [Phenomenology of food behavior in the continuum «norm - pathology»]. Kherson : PP Vyshemyrskyi V. S. [in Ukrainian].

Shebanova, V. I. (2017). Psykholohiia kharchovoi povedinky [Psychology of food behavior]. Doctor's thesis. Kyiv [in Ukrainian].

Shebanova, V. I. (2019). Psykholohichni umovy ta tekhnolohii formuvannia zdoroviazberezhuvalnoi kompetentnosti shchodo harchovoi povedinky. [Psychological conditions and technologies for the formation of health competence in food behavior]. Psykholohichni tekhnolohii efektyvnoho funktsionuvannia ta rozvytku osobystosti - Psychological technologies of effective functioning and development of personality, (pp. 506-530). Sumy : Vyd-vo SumDPU imeni A. S. Makarenka [in Ukrainian].

Chevinsky, J. D., Wadden, T. A., \& Chao, A. M. (2020). Binge Eating Disorder in Patients with Type 2 Diabetes: Diagnostic and Management Challenges. Diabetes, metabolic syndrome and obesity: targets and therapy, 13, 1117-1131. Retrieved from https://doi.org/10.2147/ DMSO.S213379.

(c) Shebanova Vitaliia

DOI (article): https://doi.org/10.32626/2227-6246.2021-51.241-265 
DOI: https://doi.org/10.32626/2227-6246.2021-51 2021. випуск 51

da Luz, F. Q., Hay, P., Touyz, S., \& Sainsbury, A. (2018). Obesity with Comorbid Eating Disorders: Associated Health Risks and Treatment Approaches. Nutrients, 10 (7), 829. Retrieved from https://doi. org $/ 10.3390 /$ nu10070829.

Fisher, C. A., Skocic, S., Rutherford, K. A., \& Hetrick, S. E. (2018). Family therapy approaches for anorexia nervosa. The Cochrane database of systematic reviews, 10 (10), CD004780. Retrieved from https:// doi.org/10.1002/14651858.CD004780.pub3.

Gutierrez, E., \& Birmingham, C. L. (2020). Editorial: New Perspectives to Unlock the Current Impasse in Treating Anorexia Nervosa. Frontiers in psychology, 11, 207. Retrieved from https://doi.org/10.3389/ fpsyg.2020.00207.

Rousselet, M., Guérineau, B., Paruit, M., Guinot, M., \& et all. (2017). Disordered eating in French high-level athletes: Association with type of sport, doping behavior, and psychological features. Eating and Weight Disorders, 22, 61-68. Retrieved from https://doi.org/ 10.1007/s40519-016-0342-0.

Saltzman, J. A., \& Liechty, J. M. (2016). Family correlates of childhood binge eating: A systematic review. Eating Behaviors, 22, 62-71. Retrieved from https://doi.org/10.1016/j.eatbeh.2016.03.027.

Schaumberg, K., Welch, E., Breithaupt, L., Hübel, C., \& et all. (2017). The Science Behind the Academy for Eating Disorders' Nine Truths About Eating Disorders. European eating disorders review: the journal of the Eating Disorders Association, 25 (6), 432-450. Retrieved from https://doi.org/10.1002/erv.2553.

Troscianko, E. T., \& Leon, M. (2020). Treating Eating: A Dynamical Systems Model of Eating Disorders. Frontiers in psychology, 11, 1801. Retrieved from https://doi.org/10.3389/fpsyg.2020.01801.

Zipfel, S., Giel, K. E, Bulik, C. M, Hay, P., \& et all. (2015). Anorexia nervosa: Aetiology, assessment, and treatment. Lancet Psychiatry, 2 , 1099-1111. Retrieved from https://doi.org/10.1016/S2215-0366(15) 00356-9.

\section{Шебанова Валерія. Модель допомоги людям із проблемною харчовою поведінкою та порушеннями ваги}

\section{АНОТАЦІЯ}

Мета статmі - спираючись на засади синергетичної концепції виникнення та розвитку проблемної харчової поведінки у континуумі «норма - патологія», визначити особливості надання допомоги людям із проблемною харчовою поведінкою та порушеннями ваги на різних фракталах.

(C) Shebanova Vitaliia

DOI (article): https://doi.org/10.32626/2227-6246.2021-51.241-265 
DOI: https://doi.org/10.32626/2227-6246.2021-51 2021. випуск 51

Для розв'язання поставлених у роботі завдань використано такі теоретичні методи дослідження: метод аналізу наукової літератури, узагальнення.

Результати дослідження показали, що синергетика у сфері психології харчової поведінки має значний евристичний потенціал, який визначає еволюційну методологію терапії та психокорекції з урахуванням феноменів самоорганізації особистості у терапевтичному просторі (автономності, компетентності, власної самоцінності, духовної зрілості тощо). Обгрунтовано, що синергетична методологія є інструментом аналізу нелінійної ситуації розвитку харчової поведінки. Описано, що завдання фахівців полягає в організації допомоги людям із проблемними формами харчової поведінки, спрямованої на пошук ресурсів для нормалізації патернів харчової поведінки та ваги тіла.

Висновки. Синергетичні принципи та фрактальні модульні компоненти концептуальної моделі як цілісної системи дають підстави стверджувати, що траєкторія розвитку в точках біруркації може змінитися за рахунок мобілізації ресурсного потенціалу - активізації захисних і компенсаторних процесів тілесності.

Це дозволяє окреслити можливість підвищення ефективної допомоги людям із проблемними стратегіями харчової поведінки та деформаціями ваги за рахунок: 1) з'ясування особливостей суб'єктивних дискурсів як внутрішніх орієнтирів, що детермінують викривлені патерни харчовоі поведінки та, відповідно, є мішенями корекції; 2) переосмислення онтологічних проблем існування-буття та значення духовності як ресурсного потенціалу особистості, котра через діяльність духу вдосконалює себе і соціально-культурне середовище; 3) організації профрілактичної роботи на етапах латентного й ініціального фракталів з урахуванням чинників впливу; 4) створення мультидисциплінарних бригадних форм, які включають фахівців із різних галузей знань (психологів, педагогів, соціологів, духівництво, медиків різних спеціалізацій тощо); 5) створення індивідуальних програм нормалізації харчової поведінки на підставі загальних принципів і нового підходу до профрілактики, корекції та реабілітації людей із проблемними стратегіями харчової поведінки та дерормаціями ваги.

Ключові слова: психологія харчової поведінки, проблемна харчова поведінка, порушення ваги тіла, синергетична модель біо-психо-соціо-духовного розвитку харчової поведінки у континуумі «норма - патологія», модель допомоги.

(c) Shebanova Vitaliia

DOI (article): https://doi.org/10.32626/2227-6246.2021-51.241-265 
DOI: https://doi.org/10.32626/2227-6246.2021-51

2021. випУСК 51

Шебанова Валерия. Модель помощи людям с проблемным пищевым поведением и нарушениями веса

\section{АННОТАЦИЯ}

Цель статьи - опираясь на принципы синергетической концепции возникновения и развития проблемного пищевого поведения в континууме «норма - патология», определить особенности оказания помощи людям с проблемным пищевым поведением и нарушениями веса на разных фракmaлах.

Для решения поставленных в работе задач использованы следующие теоретические методы исследования: метод анализа научной литературы, обобшение.

Результаты исследования показали, что синергетика в области психологии пищевого поведения имеет значительный эвристический потенциал, который определяет эволюционную методологию терапии и психокоррекции с учетом феноменов самоорганизации личности в терапевтическом пространстве (автономности, компетентности, собственной самоценности, духовной зрелости и др.). Обосновано, что синергетическая методология является инструментом анализа нелинейной ситуации развития пищевого поведения. Описано, что задача специалистов заключается в организации помощи людям с проблемными формами пищевого поведения, направленной на поиск ресурсов для нормализации паттернов пищевого поведения и веса тела.

Выводы. Синергетические принципы и фрактальные модульные компоненты концептуальной модели как целостной системы дают основания утверждать, что траектория развития в точках бифуркации может измениться за счет мобилизации ресурсного потенциала-активизации защитных и компенсаторных процессов телесности.

Это позволяет определить возможность повышения эффективной помощи людям с проблемными стратегиями пищевого поведения и деформациями веса за счет: 1) выяснения особенностей субъективных дискурсов как внутренних ориентиров, детерминирующих искривленные паттерны пищевого поведения и, соответственно, являющихся мишенями коррекции; 2) переосмысления онтологических проблем существования-бытия и значения духовности как ресурсного потенциала личности, которая из-за деятельности духа совершенствует себя и социально-культурную среду; 3) организации профилактической работы (C) Shebanova Vitaliia

DOI (article): https://doi.org/10.32626/2227-6246.2021-51.241-265 http://journals.uran.ua/index.php/2227-6246 
DOI: https://doi.org/10.32626/2227-6246.2021-51 2021. ВипУСК 51

на этапах латентного и инициального фракталов с учетом факторов влияния; 4) создания мультидисциплинарных бригадных форм, включающих специалистов из разных областей знаний (психологов, педагогов, социологов, духовенство, медиков различных специализаций); 5) создания индивидуальных программ нормализации пищевого поведения на основании общих принципов и нового подхода к профилактике, коррекции и реабилитации людей с проблемными стратегиями пищевого поведения и деформациями веса.

Ключевые слова: психология пищевого поведения, проблемное пищевое поведение, нарушения веса тела, синергетическая модель биопсихо-социо-духовного развития пищевого поведения в континууме «норма-патология», модель помощи.

Original manuscript received January 04, 2021 Revised manuscript accepted February 11, 2021 